the outcome, we must consider not only the benefits. Because infants may remain positive for tuberculin for several years ${ }^{11}$ the tuberculin test is devalued as a diagnostic aid, which may lead to an incieased need for chemoprophylaxis. Doctors still have a large responsibility for diagnosing the dwindling condition of shildhood tuberculosis and for ensuring that tracing of contacts is carried out assiduously.

Reader in Paediatric Fespiratory Medicine,

MICHAEL SILVERMAN

Royal Postgraduate Medical School,

London W12 0HS

Medical Research Council Tuberculosis and Chest Diseases Unit. Tuberculosis in children: national survey of notifictions in England and Wales. Arch Dis Child 1988;63:266-76.
Research Committee of the British Thoracic Association. Effectiveness of BCG vaccination in Great Britain in 1978. Brf Dis Chest 1980;74:215-27.

Sutherland I, Springett VH. Effectiveness of BCG vaccination in England and Wales in 1983. Tubercle 1987;68:81-92.

4 Ormerod LP. Reduced incidence of tuberculosis by prophylactic chemotherapy in subjects showing strong reactions to tuberculin testing. Arch Dis Child 1987;62:1005-8.

George RH, Gully PR, Gill ON, Innes JA, Bakhshi SS, Connolly M. Outbreak of tuberculosis in a children's hospital. $\mathcal{F}$ Hosp Infect 1986;8:129-42.

$6 \mathrm{McCarthy}$ OR. Asian immigrant tuberculosis-the effect of visiting Asia. $\mathrm{Br} \mathcal{F}$ Dis Chest 1984;78:248-53.

7 Packe GE, Innes JA. Protective effect of BCG vaccination in infant Asians: a case-control study. Arch Dis Child 1988;63:277-81

8 Hadfield JW, Allan J, Windebank WJ. Sensitivity of neonates to tuberculin after BCG vaccination Br Med f 1986;292:990-1.

9 Curtis HM, Leck I, Bamford FN. Incidence of childhood tuberculosis after neonatal BCG vaccination. Lancet 1984; i: 145-8.

10 Chandra PK. Serum thymic hormone activity and cell mediated immunity in healthy neonates, preterm infants and small for gestational age infants. Pediatrics 1981;67:407-11.

11 Grindulis I, Baynham MID, Scott PH, Thompson RA, Wharton BA. Tuberculin response two years after BCG vaccination. Arch Dis Child 1984;59:514-612.

12 Cundall DB, Pearson SB. Inner city tuberculosis and immunisation policy. Arch Dis Child 1988;63:964-6.

\title{
Social security benefits for the mentally ill
}

\section{Uptake is low and information is sparse}

One result of mentaly ill people being cared for more in the community and less in hospital is that more of them are having to cope with a complex, bureaucratic, and often seemingly hostile social securitysystem. Yet the changes in the system in April 1988 make it even more important that these people cope with the system-for example, claiming an attendance allowance is crucial as it is a "passport" to higher income support or housing benefits. We have little or no information on how the mentally ill are coping with the new system, and, indeed, until last year almost nothing had been published on the mentally ill and social security. Islington People's Rights did something to correct this ignorance by publishing a study of the uptake of social security benefits by the mentally ill in the borough. ${ }^{1}$

Contrary to assumptions that patients in hospital were correctly advised about benefits, the study showed that, although some help was available, important benefits were unclaimed. For example, there was serious underutilisation of the attendance allowance available to patients spending part of their time at home and needing constant or frequent supervision there because claims had not been made on their behalf. Patients about to be discharged from hospital had not been informed about the benefits they should claim. Successful integration into the community depends to some extent on freedom from financial concerns, and the absence of information is worrying.

As part of the study a detailed questionnaire about welfare benefits was given to 28 patients, 24 of whom were unemployed, attending day centres or outpatient departments. More than half of those attending outpatient departments were not receiving benefits to which they were entitled but had not laid claim. This study suggested that the mentally ill were in this respect more disadvantaged than the physically ill. Over a third of the subjects interviewed confessed to having debts and experiencing severe financial strain, a further source of stress for a vulnerable group of patients. Several interviewees made critical comments about the benefits system and the attitudes they encountered at offices of the Department of Health and Social Security. These problems may have been caused by understaffing in local offices or may reflect social attitudes to mental illness.

In the long term we need a social security system more sensitive to the needs of special groups such as the mentally ill. In the short term the problems might be lessened by the routine provision of information about benefits for patients about to be discharged from hospital, residents of local authority hostels and group homes, and patients attending community day centres for the mentally ill. This provision probably exists in many units, but it should be generally available. Additionally, welfare rights officers should be alerted to the particular needs of the mentally ill, and community psychiatric nurses and social workers should be trained to tell their clients about their rights to benefits.

These comments are based on the findings of a small study in a single health district, and after extensive inquiry I failed to uncover other sources of information about the utilisation of the social security system by the mentally ill. Islington People's Rights is to be congratulated for highlighting an important deficit in care, but more studies are needed. Readiness to fund such research is a measure of society's concern about the lot of the mentally ill.

Senior Lecturer in General Practice,

B E MARKS

University of Manchester,

Rusholme Health Centre,

Manchester M14 5NP

1 Linney J, Boswell C. Social security and mental illness. London: Islington People's Rights, 1987.

\section{Correction}

Regular Review: Echocardiography

We regret that in this regular review by Dr J B Chambers and others (29 October, $\mathrm{p}$ 1071) the pictures in figure 5 were transposed. 